\title{
THE PERMEABILITY OF THE GASTRO-ENTERIC TRACT OF INFANTS TO UNDIGESTED PROTEIN*
}

\author{
OSCAR M. SCHLOSS, M.D., AND THACHER W. WORTHEN, M.D. \\ NEW YORK \\ HARTFORD, CONN.
}

\section{INTRODUCTION}

The possible absorption of unaltered or incompletely digested protein is a question of more than academic interest. It is well established that the introduction of foreign protein into the circulation may provoke certain specific reactions (formation of precipitins, sensitization, etc.). Nutritional disturbances in infants fed on cow's milk have been attributed to the biologic character of the food. According to our present conceptions the specific biologic properties of animal tissues reside in great part, if not entirely, in the protein constituents. It is generally believed, however, that the proteins are split into amino-acids before absorption. If such is universally true, biologic reactions to cow's milk would be unlikely, as it has been demonstrated that specificity is lost in protein cleavage products lower than the peptones.

Ganghofer and Langer ${ }^{1}$ found that the intestinal tract of young animals permitted the passage of heterologous protein (beef, egg) as determined by precipitin tests applied to the blood serum. When physiologic quantities were given, this occurred only in animals less than eight days old. After this time the tests were not positive, except with massive doses of the foreign protein or when the intestinal tract was subjected to chemical injury. In two debilitated infants, absorption of undigested egg protein was demonstrated by precipitin tests applied to the blood.

Mayerhofer and Pribam ${ }^{2}$ observed that in acute enteritis there was an increased permeability of the intestinal wall to both crystalloids and colloids. Hamburger and Sperk $^{3}$ could not demonstrate absorption of foreign protein when small quantities were fed, nor did they find

\footnotetext{
* From the Laboratory of Biological Chemistry of Columbia University, at the College of Physicians and Surgeons, and the New York Nursery and Child's Hospital, New York.

1. Ganghofer and Langer: Ueber die Resorption genuiner Eiweisskörper im Magendarmkanal neugeborener Tiere und Säuglinge, München. med. Wchnschr., 1904, 1i, 1497.

2. Mayerhofer, E., and Pribam, E.: Ueber die Beeinflussung der Diffusionsvorgänge an frischen tierischen Darmmembranen, Biochem, Ztschr., 1910, xxiv, 453; Das Verhalten der Darmwand als osmotische Membran dei akuter und chronischer Enteritis, Wien. klin. Wchnschr., 1909, xxii, 875.

3. Hamburger, F., and Sperk, B.: Biologische Untersuchungen über Eiweissresorption vom Darm aus, Wien. klin. Wchnschr., 1904, xvii, 641.
} 
an increased permeability of the intestinal tract to undigested protein in young animals. Uffenheimer's ${ }^{4}$ experiments led to the same conclusion.

On the other hand, Lawatschek* has recently found that the intestinal tract of very young infants is more permeable to foreign protein.

Uhlenhuth $^{5}$ found that prolonged feeding of egg protein to rabbits caused the development of specific precipitins in the blood, thus indicating the entrance of egg protein into the general circulation. In healthy men Ascoli ${ }^{6}$ was able to demonstrate the presence of egg protein in the blood serum by precipitin tests as early as one and three-fourths hours after the egg was ingested. In the urine, egg protein and human protein could be demonstrated. Inouye ${ }^{7}$ obtained practically the same results.

Moro ${ }^{8}$ found milk precipitins in the blood of two out of twenty-two investigations on atrophic infants (postmortem). In one case there was complement deviation for milk protein. Bauer ${ }^{9}$ demonstrated precipitins and also complement deviation for milk in the blood of four atrophic infants.

In contrast to these positive results Krasnogorski ${ }^{10}$ did not find precipitable milk protein in the urine of infants suffering from nutritional disorders.

Recent experiments by Modigliani and Benini, $\uparrow$ however, indicate that casein may be absorbed unaltered. Their technic consisted of

\footnotetext{
* Lawatschek: Die enterale Resorbtion von genuinen Eiweiss bei Neugeborenen und darmkranken Säuglingen, etc. Prag. Med. Wchnschr, 1914, xxxix, 185.

† Permeability of Intestinal Tract of Infants for Casein of Cow's Milk, Policlinico, Dec. 1915, abstr. in Jour. Am. Med. Assn, 1915, 1xiv, 475.

4. Uffenheimer, A.: Zur Frage der intestinalen Eiweiss Resorption, Jahrb. f. Kinderh., 1906, lxiv, 383.

5. Uhlenhuth: Neuer Beitrag zum spezifischen Nachweis von Eiereiweiss auf biologischen Wege, Deutsch. med. Wchnschr., 1900, xxvi, 734. Haendel: Untersuchungen über die praktische Verwertbarkeit der anaphylaxie zur Erkennung und Unterscheidung verschiedener Eiweissarten, Ztschr. f. Immunitätsforsch., 1910, iv, 761.

6. Ascoli, M.: Ueber den Mechanismus der Albuminurie durch Eiereiweiss, München. med. Wchnschr., 1902, xlix, 398; Neue Tatsachen und neue Ausblick in der Lehre der Ernährung, München. med. Wchnschr., 1903, i, 201.

7. Inouye: Ueber alimentare Albuminurie, Deutsch. Arch. f. klin. med., 1903, $1 \mathrm{xxv}, 378$.

8. Moro, E.: Kuhmilchpräzipitin im Blute eines $4 \frac{1}{2}$ Monate alten, Atrophikers, München. med. Wchnschr., 1906, liii, 214.

9. Bauer, J.: Ueber den Nachweis der precipitablen Substanz der Kuhmilch im Blute atrophischer Säuglinge, Berl. klin. Wchnschr., 1906, xliii, 711.

10. Krasnogorski, N.: Ueber die Herkunft des Harneiweiss bei Albuminurien der Säuglinge, Ztschr. f. Kinderh., 1912, iv, 526.
} 
testing the blood serum of infants affected with gastroenteric disorders with anti casein serum from rabbits. The patients were receiving cow's milk as food.

The results obtained by means of anaphylactic tests on animals are closely analogous to those in which the precipitin test was used. Rosenau and Anderson ${ }^{11}$ and others showed that the feeding of foreign protein caused the animal to become sensitized to the protein fed. This indicated that some of the protein, at least, was absorbed in a partially digested state. Vaughan, Cummings and McGlumphy ${ }^{12}$ demonstrated, by anaphylactic tests, that rabbits absorb incompletely digested protein through the gastro-enteric tract. After feeding egg protein the blood of rabbits was capable of sensitizing guinea-pigs to egg protein. Van Alstyne and Grant, ${ }^{13}$ and Van Alstyne, ${ }^{14}$ found that dogs absorb foreign protein through Thiery-Villa fistulas in sufficient quantities to sensitize guinea-pigs. In a patient subject to alimentary albuminuria they found that the protein in the urine sensitized both to the foreign protein fed and to human protein. This observation is in accord with the work of Uhlenhuth and others with the precipitin test.

Lust $^{15}$ has recently studied the absorption of heterologous protein by infants affected with nutritional disorders. The precipitin test applied to the urine was the means of identification, though in some cases the anaphylactic test was used. His results showed that in normal infants undigested egg or beef protein is not absorbed. In nutritional disorders he found that egg protein appeared in the urine after ingestion. Beef protein was absorbed unchanged in very few cases. The experiments of $\mathrm{Hyash}^{16}$ and Lawatschek gave results similar to those of Lust.

Our own investigations were undertaken in the effort to determine the possibility of absorption of undigested protein by infants. For this purpose precipitin and anaphylactic tests were used and the blood was examined for the presence of reaction substances (protective ferments of Abderhalden).

11. Rosenau and Anderson: Studies on Anaphylaxis, Bull. Hygienic Lab., 1908, No. 45.

12. Vaughan, Cummings and McGlumphy: The Parenteral Introduction of Proteins, Ztschr. f. Immunitätsforsch., 1911, ix, 16.

13. Van Alstyne, E., and Grant, J. P.: The Absorption of Albumin Without Digestion, Jour. Med. Research, 1911, xxv, 399.

14. Van Alstyne, E.: Absorption of Protein Without Digestion, Arch. Int. Med., 1913, xii, 372.

15. Lust: Die Durchlässigkeit des Magendarmkanales für heterologes Eiweiss bei ernahrungsgestarten Sauglingen, Jahrb. f. Kinderh., 1913, 1xxvii, 244 and 283.

16. Hayashi, J.: Ueber die Durchlässigkeit des Sauglingsdarmes für artfremdes Eiweiss und Doppelzucker, Monatschr. f. Kinderh., 1914, xii, 749. 
II. ABSORPTION OF UNDIGESTED PROTEIN BASED ON THE EXAMINA-

TION OF THE URINE BY PRECIPITIN AND

ANAPHYLACTIC TESTS

In many of the experiments cited the tests for foreign protein were applied to the blood. On first thought this may seem the ideal method, but as applied to infants it has at least one insurmountable obstacle. It has been shown by Ascoli, Lust and others that the foreign protein is present in the blood stream for a very short time and the detection of its presence would require frequent examinations, obviously a procedure not permissible in infants, especially those affected with nutritional disorders. On the other hand, it has been found that the foreign protein is present in the urine over a longer period of time. The following observation made by one of us (S.) has a direct bearing on this question.

C. J. S., aged 21 years, subject to alimentary albuminuria.

The patient was given the whites of ten eggs at $8 \mathrm{a} . \mathrm{m}$. on an empty stomach. The urine was collected every hour and blood removed at intervals of one or two hours. Two cubic centimeters of urine or citrated blood were injected into the peritoneal cavity of guinea-pigs as a sensitizing dose to test for egg protein by the anaphylactic reaction. Two weeks later the animals were given 2.5 c.c. of egg white as an intoxicating dose. Two animals, weighing from 250 to $300 \mathrm{gm}$., were used in each experiment. The results are given in Table 1.

TABle 1.-The Presence of Egg Protein in the Blood and Urine After Ingestion of EgG White. Anaphylactic Test

\begin{tabular}{|c|c|c|c|}
\hline Hour & $\begin{array}{l}\text { Albuminuria } \\
\text { Heat and } \\
\text { Acetic Acid }\end{array}$ & $\begin{array}{c}\text { Anaphylactic } \\
\text { Test } \\
\text { Blood }\end{array}$ & $\begin{array}{c}\text { Anaphylactic } \\
\text { Test } \\
\text { Urine }\end{array}$ \\
\hline $7: 45$ a.m. $\ldots \ldots \ldots \ldots \ldots \ldots \ldots \ldots \ldots \ldots \ldots \ldots \ldots$ & - & - & - \\
\hline 8:00 a. m. egg ingested........ & - & .. & - \\
\hline 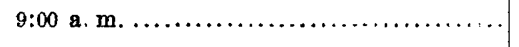 & - & $\pm^{*}$ & - \\
\hline 10:00 a. m. ....... & - & ++ & - \\
\hline 11:00 a. m. ....... & Faint trace & - & + \\
\hline $12: 00 \mathrm{~m} . \ldots \ldots \ldots$ & Heavy trace & - & $+t$ \\
\hline 1:00 p. m. ....... & Marked & .. & +++ \\
\hline 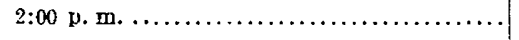 & Trace & - & ++ \\
\hline $3: 00$ p. m. $\ldots \ldots \ldots \ldots \ldots \ldots \ldots \ldots \ldots \ldots \ldots \ldots \ldots \ldots \ldots \ldots$ & - & . & - \\
\hline
\end{tabular}

* \pm equais questionable reaction; + equals mild, ++ marked and +++ severe reaction.

This observation demonstrates that the foreign protein appears in the blood stream earlier, but persists in the urine for a longer time. In consideration of these results and the factors already discussed, the tests in our observations were applied to the urine. 
1. Precipitin Tests.-The precipitating serum for egg white was obtained from rabbits in the usual way by giving three or more intravenous injections of 2.5 c.c. of egg white. The second and third injections were given at intervals of four and three days, respectively. If, after the third injection, the egg serum exhibited a titer of 1:100,000 or more, the animal was bled to death, the serum passed through a Berkefeld filter and preserved in sealed glass capsules until used. Otherwise, further injections of egg white were given until a serum of sufficient strength was obtained. No serum with a titer of less than $1: 100,000$ was used, and in some instances it ranged from $1: 500,000$ to $1: 1,000,000$.

In accordance with the experience of others, it was found impossible to obtain regularly a mjlk precipitating serum of high titer. Many animals were treated with milk, whey, casein, and the whey proteins precipitated by saturation with ammonium sulphate. One animal treated by the last method gave a serum with a titer of $1: 20,000$. This serum was used for tests to be described later. Further trials by the same procedure were futile, though the technic was as nearly as possible identical to that first used. Serums were obtained with titers of $1: 300$ to $1: 700$, but, owing to the negative results of Krasnogorski with such serums, they were considered inadequate.

The precipitin tests for milk were carried out on mixed specimens of urine from infants fed on cow's milk. In the egg tests the infants were fed the whites of from one to two eggs and the urine collected for six hours used for the examination. In all cases the urine was tested pure, diluted $1: 5,1: 10$, 1:50 and 1:100 with normal saline. Two-tenths cubic centimeter of the precipitating serum was added to each tube containing 1 c.c. of the plain or undiluted urine. The tubes were incubated at $37.5 \mathrm{C}$. for one hour and the results noted. They were placed on ice for twelve hours, and in case a definite precipitate was not apparent in the tubes considered positive after one hour incubation, the test was regarded as negative. Cases in which the precipitate appeared only after twelve hours were also considered negative. In each experiment, control tests were carried out with 0.2 c.c. of normal rabbit serum in place of the precipitating serum, and also with 0.2 c.c. of the precipitating serum added to normal urine. The urines were all faintly acid or amphoteric to litmus, and, when at all concentrated, were dialyzed through collodion for twenty-four hours before the test was applied.

\section{DISCUSSION}

The results relating to cow's milk are shown in Tables 2, 3 and 4 . Judging from these results, in normal infants fed on cow's milk no foreign protein recognizable by the precipitin test appears in the urine. Two of the four atrophic infants tested excreted protein in the urine which gave a positive test with milk precipitating serum. The results in gastro-enteric disorders ${ }^{17}$ were identical. In two of the four cases

17. We make no attempt to follow any definite clinical or pathologic classification of these cases. The term gastro-enteric disorder is merely used to designate nutritional disturbances characterized by loss of weight, vomiting, loss of appetite, frequent bowel movements of more fluid consistency than normal, of abnormal color and odor. The terms mild, moderate and severe refer mainly to the general disturbances such as loss of weight or appetite, fever, vomiting and symptoms of intoxication. In the absence of a satisfactory etiologic classification we feel that it is safer and perhaps clearer to classify the cases in this way rather than to attempt classification based on pathologic lesions, the supposed infecting micro-organism or an apparent intolerance to an individual food substance. 
observed a precipitate was obtained in the urine when treated with the anti-whey serum.

These results indicate, therefore, that in atrophy or gastro-enteric disorders whey protein may be absorbed from the gastro-enteric tract without complete digestion and appear in the urine. Krasnogorski, using the precipitin and complement deviation tests obtained negative results in similar observations. His precipitating serum, however, had a titer of $1: 600$ while ours was $1: 20,000$. This probably explains the difference in results. As mentioned previously, Modigliani and Benini were able to show that casein may be absorbed by infants affected

TABLE 2.-Precipitin Tests for Cow's Milk in Urine of Normal Infants

\begin{tabular}{c|c|c|c|c}
\hline \hline Number & $\begin{array}{c}\text { Age, } \\
\text { Months }\end{array}$ & $\begin{array}{c}\text { Weight, } \\
\text { Pounds }\end{array}$ & $\begin{array}{c}\text { Albuminuria, } \\
\text { Heat and } \\
\text { Acetic Acid }\end{array}$ & Preclpitin Reaction \\
\hline 1 & 5 & $141 / 2$ & - & - \\
2 & 5 & $13 \% / 4$ & - & - \\
8 & 6 & 15 & - & - \\
4 & 6 & $151 / 2$ & - & - \\
6 & 8 & 17 & - & - \\
\hline
\end{tabular}

TABLE 3.-Precipitin Tests for Cow's Milk in Urine of Infants SufferING FROM ATROPHY

\begin{tabular}{c|c|c|c|c}
\hline \hline Number & $\begin{array}{c}\text { Age, } \\
\text { Months }\end{array}$ & $\begin{array}{c}\text { Weight, } \\
\text { Pounds }\end{array}$ & $\begin{array}{c}\text { Albuminuria, } \\
\text { Heat and } \\
\text { Acetic Acld }\end{array}$ & Precipitin Reaction \\
\hline 1 & 5 & 9 & - & Negative \\
2 & 7 & $81 / 2$ & Faint trace & Positive pure, 1-5 \\
3 & 8 & 8 & - & - \\
4 & 9 & $91 / 2$ & Trace & Positive pure, 1-5 \\
\hline
\end{tabular}

TABLE 4.-Precipitin Tests for Cow's Milk in Urine of Infants SuffERING FROM ACUTE GaStro-Enteric Disorders

\begin{tabular}{c|c|c|c|c}
\hline \hline Number & $\begin{array}{c}\text { Age, } \\
\text { Months }\end{array}$ & $\begin{array}{c}\text { Weight, } \\
\text { Pounds }\end{array}$ & $\begin{array}{c}\text { Albuminuria, } \\
\text { Heat and } \\
\text { Acetic Acid }\end{array}$ & Precipitin Reaction \\
\hline 1 & 8 & 9 & Trace & Positive pure \\
2 & 6 & $11 \% / 4$ & - & - \\
3 & 8 & $18 \frac{112}{18}$ & - & - \\
4 & 8 & 18 & Faint trace & Positive pure, 1-5, 1-10 \\
\hline
\end{tabular}


with intestinal disease. The precipitin tests with egg protein are shown in Tables 5 to 10 inclusive. Tests were made on fourteen infants without symptoms of gastro-enteric disturbance. In one infant egg protein appeared in the urine after the ingestion of the whites of two eggs, although the test was negative when one egg white was ingested. In another case the test was positive when the whites of one and one-half eggs were given. In the remaining twelve normal infants there was no evidence of absorption of unaltered egg white.

These results indicate that, when given in moderate amounts, egg white is absorbed by normal infants only after complete digestion; or, to be strictly accurate, none of the foreign protein appears in the urine. Our observations differ from those of Lust in that two positive results were obtained in experiments on fourteen normal infants. His results were entirely negative.

Seven infants with mild gastro-enteric disorders were tested. (Table 6). In two cases egg protein was excreted in the urine. In one of these the test was negative after the ingestion of one egg but was positive when two eggs were given.

In three of the four cases of moderate severity tested (Table 7), positive results were obtained. Case 4 is of special interest since it was possible to make four tests at different stages of the disease. At the onset of the disease the test was negative. During the period of maximum severity the test was positive and after improvement was negative.

Of the six cases with severe symptoms all showed a positive reaction at some time during the disease (Table 8).

Six cases of eczema were investigated and the result was positive in three.

Considered collectively these results show that after the ingestion of moderate amounts of egg white normal infants rarely excrete egg protein in the urine recognizable by the precipitin test. In gastro-enteric disorders the mucous membrane becomes permeable, the degree of permeability being in direct ratio, apparently, to the severity of the disorder. These results practically coincide with those of Lust. ${ }^{18}$ Judging from the results in six cases there is a tendency for infants with eczema to absorb incompletely digested egg white.

18. In the interpretation of our results, we assume that the appearance of precipitable egg protein in the urine is indicative of its absorption in undigested or incompletely digested forms. While this assumption is in accord with accepted ideas, there are other possibilities which must be mentioned: (1) That small amounts of undigested egg protein may be absorbed but destroyed or fixed in some organ so that it does not appear in the urine; (2) that the absorption of small amounts of partially digested egg protein is usual, and the appearance of the foreign protein in the urine is not a direct indication of its absorption, but rather of the failure of the normal mechanism for its destruction. 
2. Anaphylactic Tests.-When the urine contained coagulable protein (heat and acetic acid, cold nitric acid, tests) it was precipitated by saturation with ammonium sulphate and the precipitant removed by dialysis through collodion. A quantity of this protein solution equivalent to 3 c.c. of the urine was injected into the peritoneal cavity of a 250 to $300 \mathrm{gm}$. guinea-pig. This served as the sensitizing dose. In the absence of albuminuria 3 c.c. of the urine was used for this purpose. After the lapse of twenty-one days an intoxicating dose of 2 c.c. of egg white was given intraperitoneally. The animals were watched closely and the symptoms recorded. All equivocal reactions were excluded. The symptoms on which the degree of shock was estimated were as follows:

Mild: Uneasiness accompanied by bucking movements. Roughening of coat. Sneezing, scratching of nose, neck and forelegs. Slight to moderate dyspnea accompanied by indrawing of sides. Slight fall of temperature-1.6 to $2.5 \mathrm{~F}$.

Moderate: The above symptoms in greater degree, with especial reference to fall of temperature, dyspnea and weakness.

Severe: Paralysis of hind limbs. Convulsions. Fall of temperature from 5 to $8 \mathrm{~F}$. Often death. Marked distention of lungs at necropsy.

\section{DISCUSSION}

Analysis of the results shown in Tables 5 to 10 admits of the foilowing summary:

After the ingestion of egg by normal infants, the urine did not sensitize to egg white though in two cases a positive precipitin reaction occurred.

The test was negative in two cases of mild gastro-enteric disorder, though in one of these the precipitin reaction was positive.

Of the cases of moderate severity the anaphylactic test was positive in one of three cases tested. In all three the precipitin reaction was obtained.

Eight of the severe cases were tested and in five the test was positive. In all of the urines positive with the anaphylactic test the precipitin reaction was also positive.

The urine of two of the three patients with eczema tested sensitized guinea-pigs to egg protein. In both the precipitin reaction was present.

Ten cases of malnutritition or atrophy were observed and in five the test was positive. It was never positive in the presence of a negative precipitin reaction, though in three cases with a positive precipitin test the anaphylactic reaction was absent.

The general conclusions to be drawn from the results of the two tests are identical, though the precipitin reaction was positive in a greater number of cases than the sensitization test. The precipitin reaction was often present in urines apparently free from coagulable protein (clinical tests). The anaphylactic test, however, seemed to bear a direct relationship to the presence of clinical albuminuria following the ingestion of egg. It was never possible to sensitize guinea-pigs to egg white with urine which gave no precipitate with heat and acetic 
acid. In a few instances protein-containing urine did not sensitize to egg white, but in the greater number of such cases the albuminuria was entirely independent of the ingestion of egg.

Of considerable interest is the fact that human urine, free from coagulable protein, can sensitize to human protein. This fact has been pointed out by Wells, ${ }^{19}$ Uhlenhuth and others. It would thus seem that human protein derivatives below the coagulable forms are capable of sensitizing to the whole protein.

Our results offer a possible explanation for the rather contradictory results of Ascoli and others who used the precipitin test, and of Wells ${ }^{19}$ who used the anaphylactic reaction, as the means of identification of egg protein in human urine. As mentioned previously, Ascoli and others detected biologically precipitable egg protein in the blood and urine of normal individuals after the ingestion of egg. Wells, on the other hand, could not sensitize guinea-pigs to egg protein with the urine of patients who had ingested large amounts of egg white, even in instances when the urine contained small amounts of coagulable protein.

From our results it seems probable that the two tests although of the same general significance differ greatly in sensitivity, at least when applied to the identification of egg white in urine. The precipitin reaction is often positive in the presence of a negative anaphylactic test and it seems probable that the two reactions are not dependent absolutely on the same substances. This assumption is strengthened by the fact that the anaphylactic reaction was never positive in the absence of coagulable protein, which was not true of the precipitin test. ${ }^{20}$

\section{TESTS FOR PROTECTIVE FERMENTS (ABDERHALDEN) IN BLOOD SERUM}

The work of Abderhalden ${ }^{21}$ and his co-workers is too well known to require any detailed description. In simplest form the theory is as follows: Foreign protein, when absorbed parenterally, stimulates the formation of certain protective substances which are capable of hydrolyzing this variety of protein. The claims of Abderhalden indicate that there is a great degree of specificity in the action of the antibody. The detection of such ferments is accomplished by digesting the suspected protein with the blood serum to be tested in a special dialyzing bag and

19. Wells, H. G.: Observations on Alimentary Albuminuria by Means of the Anaphylaxis Reaction, Jour. Am. Med. Assn., 1909, lii, 863.

20. This statement applies only to the identification of egg protein in the urine, for as stated previously, human urine which contains no coagulable protein may sensitize to human protein.

21. Abderhalden, E.: Der Nachweis blutfremden Stoffe, etc., Beitr. z. klin. Infectionskrank. u. Immunitätsforsch., 1913, i, 243 Abwehrfermente, Springer, Berlin, 1914. 


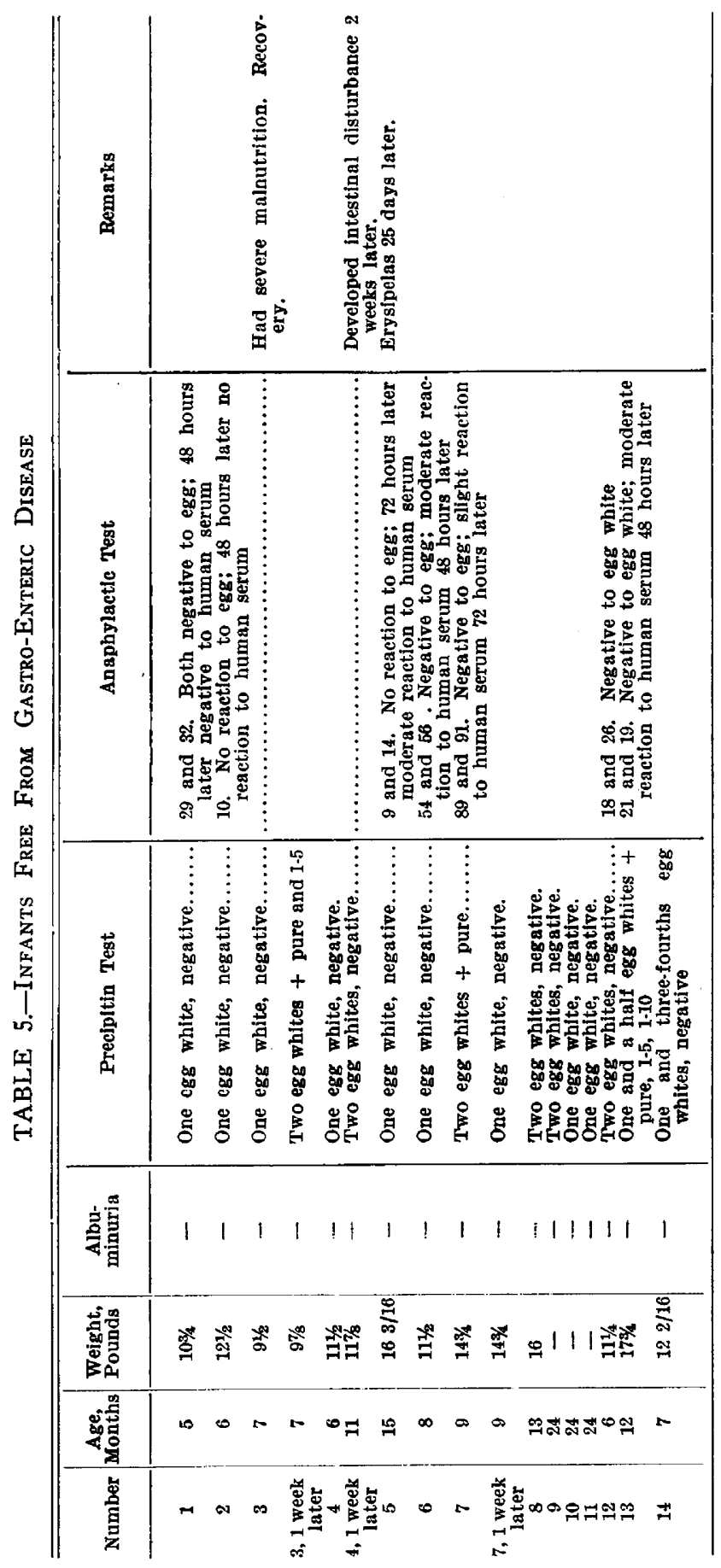




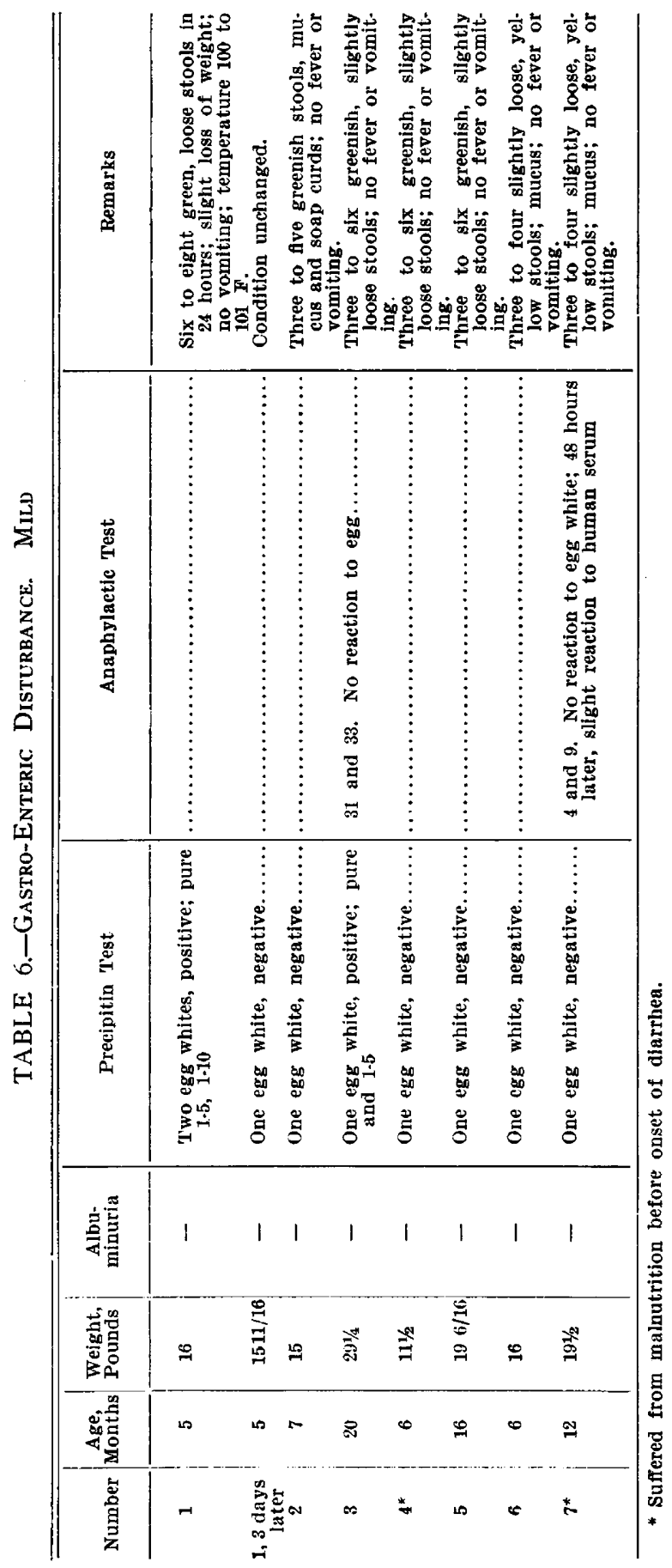




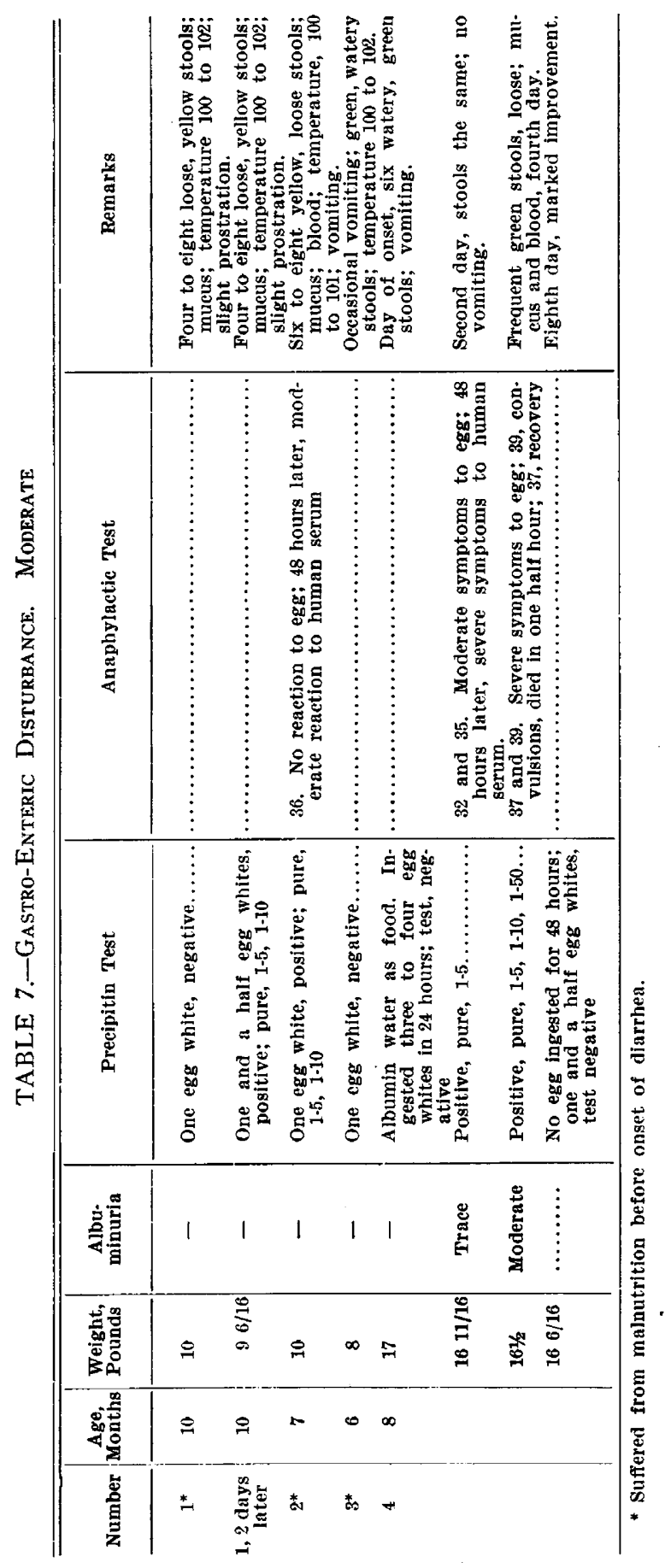




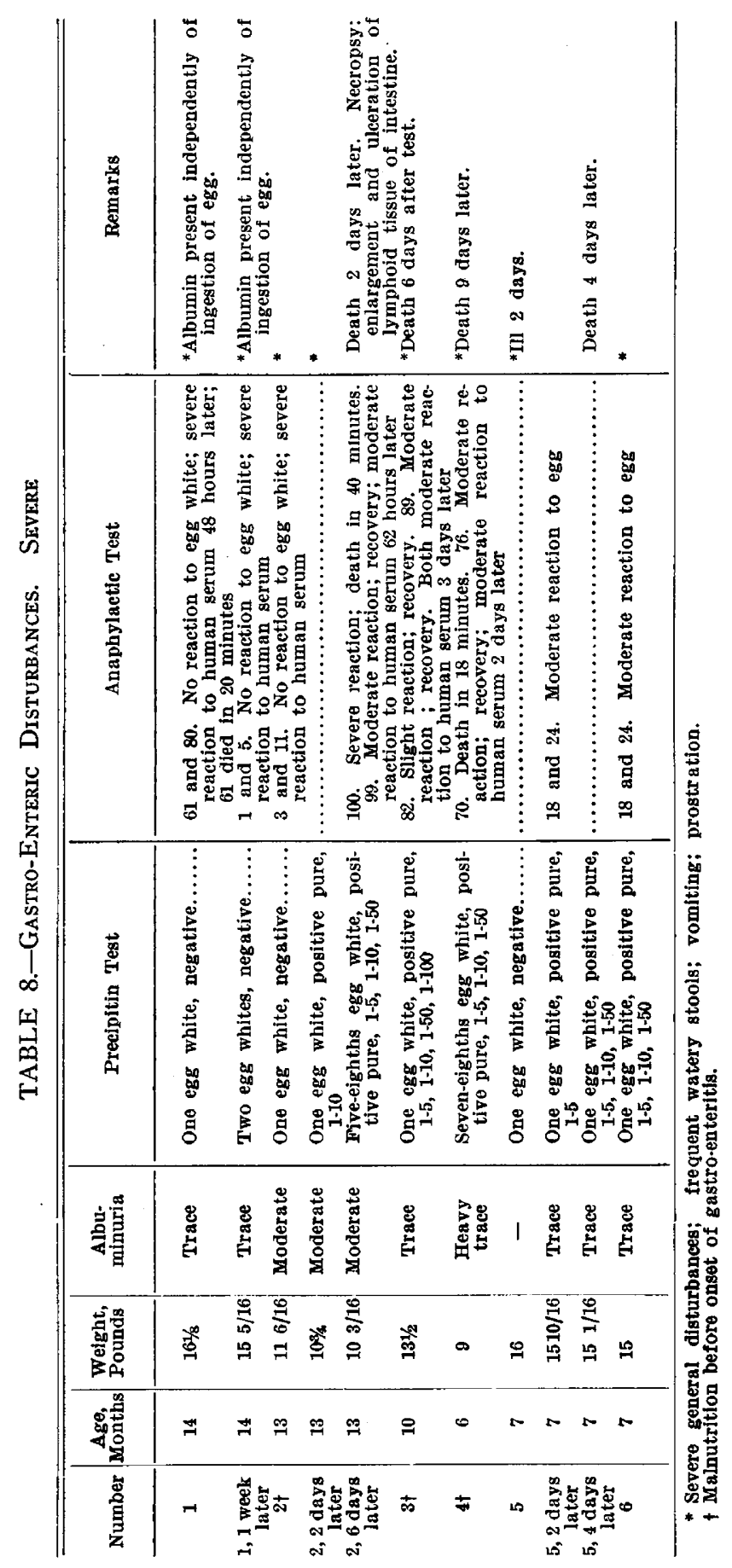




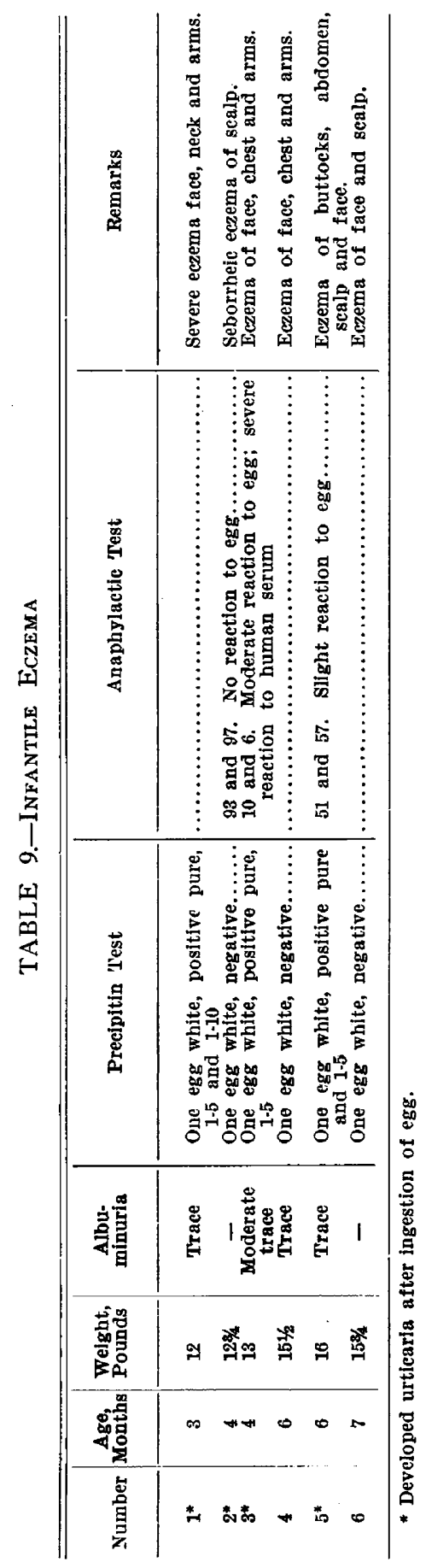




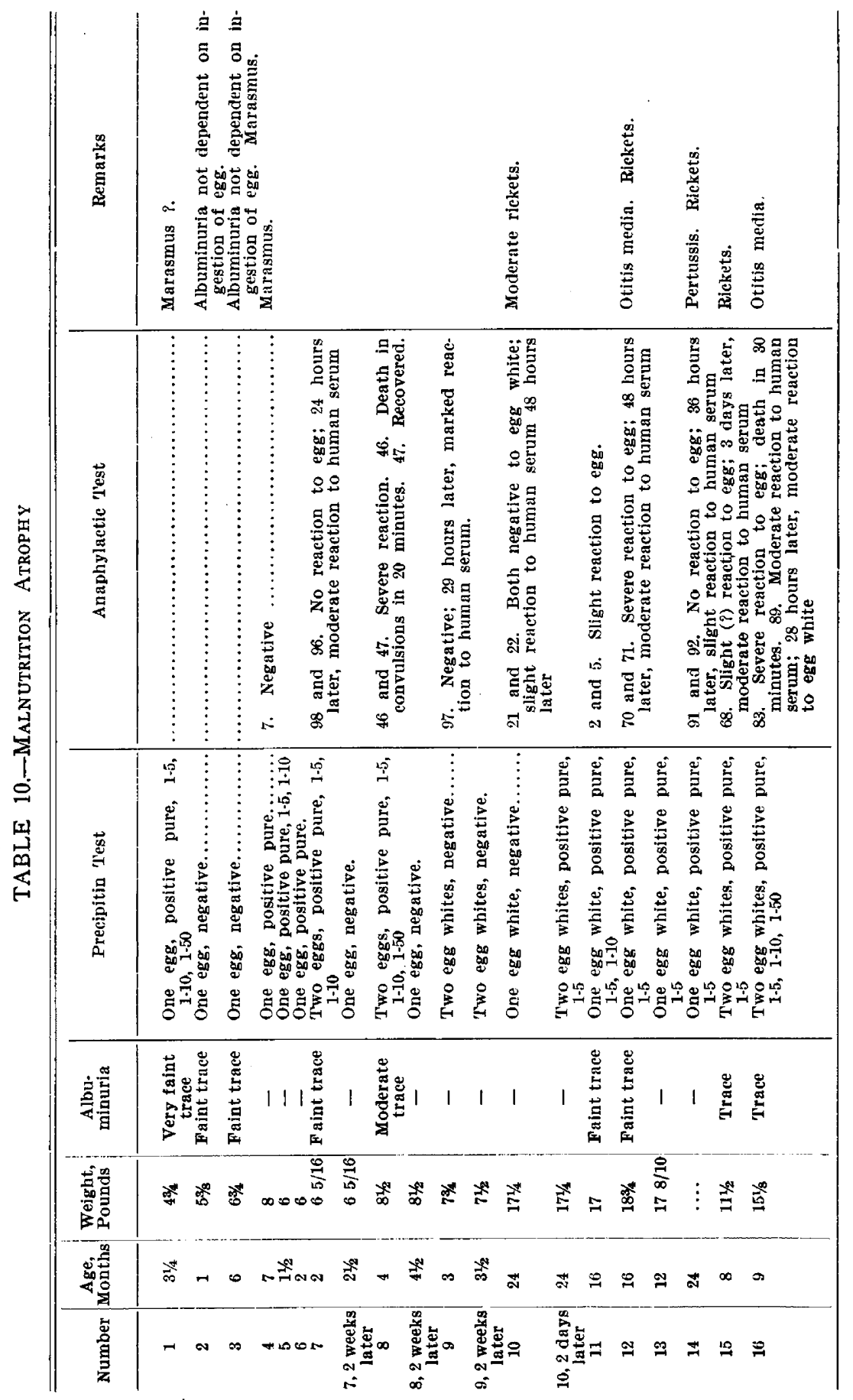


testing the dialysate for protein cleavage products. Properly controlled, a positive reaction should indicate the presence of a proteolytic ferment in the serum capable of digesting the protein used.

Assuming that the contentions of Abderhalden and his co-workers are correct, the presence of a protease capable of digesting milk in the blood serum of nurslings would indicate that undigested milk protein had been absorbed and had provoked the formation of protective ferments. It was with this hypothesis in mind that we used the test.

Technic.-The procedure of Abderhalden was carefully followed. Milk and egg protein, coagulated by heat and acetic acid, were carefully washed until free from substances capable of giving a positive ninhydrin reaction. These proteins were kept on ice in chloroform water and were tested from time to time to exclude the formation of dialyzable products.

The special dialysis bags of Schleicher and Schüll were used and each bag was tested (1) to show that it was permeable to silk peptone, and (2) that it was not permeable to the coagulated protein preparations. After use the bags were treated with boiling water and kept in sterile water under toluene. Before further use, each was again tested as mentioned above. ${ }^{22}$

The serum was collected in the usual way and all specimens tinged to the slightest degree, with blood, were discarded. Two control tests were made with each experiment: (1) The serum heated to destroy any ferment present was dialyzed with the protein to be tested; $(2)$ the fresh serum was dialyzed alone. Such tests should be negative.

The only departure from the technic advised by Abderhalden was the use of 0.8 c.c. instead of 1.5 c.c. of - serum. This was necessitated by the smaller amounts of blood obtainable from infants.

\section{DISCUSSION OF RESULTS}

The results of the tests are shown in Tables 11 to 15 , inclusive. The reaction was present often in apparently normal infants and children. It was present with greatest frequency in cases of chronic malnutrition and subacute intestinal disorders. Of interest is the fact that the serum of several infants who had never eaten egg contained a ferment capable of digesting egg protein. This finding is very difficult to explain on the basis of Abderhalden's hypothesis.

In the present state of our knowledge, a discussion of these results with any degree of assurance is impossible. Granting the correctness of Abderhalden's views, the positive tests indicate an absorption of undigested protein and have the same significance as the anaphylactic or precipitin reactions. His views, however, have not been generally accepted and there is an enormous controversial literature which it is beyond the scope of this paper to discuss. Since, therefore, the origin and function of a proteolytic ferment in the blood serum is a mooted

22. It is worthy of note that the unreliability of the dialysis bags was a tremendous obstacle in the work. A large percentage were found useless on the first tests and after use a considerable number became impermeable to peptone or permeable to the coagulated protein. 
TABLe 11.-Tests for Protease in Blood Serum of Apparently Norkal INFANTS AND ChILDREN

\begin{tabular}{|c|c|c|c|c|c|}
\hline \multirow{2}{*}{ No. } & \multirow{2}{*}{$\begin{array}{c}\text { Age, } \\
\text { Months }\end{array}$} & \multirow{2}{*}{$\begin{array}{l}\text { Welght, } \\
\text { Pounds }\end{array}$} & \multicolumn{2}{|c|}{ Protease Serum } & \multirow{2}{*}{ Remarks } \\
\hline & & & Millk & Egg & \\
\hline 1 & $\mathbf{2}$ & 10 & - & - & \\
\hline 2 & 3 & 11 & + & .. & \\
\hline 8 & 8 & 12 & - & - & \\
\hline 4 & 4 & $121 / 2$ & - & + & Had never eaten egg; cutaneous test neg. \\
\hline 5 & 6 & 16 & + & - & \\
\hline 6 & 6 & 15 & + & + & Had never eaten egg; cutaneous test neg. \\
\hline 7 & - & 14 & - & .. & \\
\hline 8 & 6 & 15 & - & .. & \\
\hline 9 & 7 & $15 \%$ & - & - & \\
\hline 10 & 8 & $173 / 2$. & + & + & \\
\hline 11 & 10 & 16 & - & - & \\
\hline 12 & 18 & $18 \%$ & - & + & \\
\hline 13 & 18 & 22 & - & - & \\
\hline 14 & 24 & 24 & - & + & \\
\hline 16 & 80 & $241 / 2$ & + & - & \\
\hline 16 & 86 & 23 & - & - & \\
\hline 17 & 88 & 24 & - & - & \\
\hline 18 & 42 & $201 / 2$ & + & - & \\
\hline 19 . & 42 & 80 & - & + & \\
\hline 20 & 48 & 82 & - & - & \\
\hline
\end{tabular}

TABLE 12.-Tests for Protease in the Blood Serum of Infants Affected WITH ECZEMA

\begin{tabular}{|c|c|c|c|c|c|}
\hline \multirow{2}{*}{ No. } & \multirow{2}{*}{$\begin{array}{c}\text { Age, } \\
\text { Months }\end{array}$} & \multirow{2}{*}{$\begin{array}{l}\text { Welght, } \\
\text { Pounds }\end{array}$} & \multicolumn{2}{|c|}{ Protease Serum } & \multirow{2}{*}{ Remarks } \\
\hline & & & Mnk & Egg & \\
\hline 1 & 5 & 12 & + & + & Had never eaten egg; cutaneous test + \\
\hline 2 & 5 & 18 & - & - & \\
\hline 8 & 5 & $123 / 2$ & - & + & Had never eaten egg; cutaneous test + \\
\hline 4 & 5 & 14 & + & - & \\
\hline 5 & 6 & $14 \frac{1}{2}$ & - & - & \\
\hline 6 & 6 & 16 & + & + & Cutaneous test + \\
\hline 7 & 6 & 15 & - & + & Outaneous test - \\
\hline 8 & 6 & $153 / 2$ & + & + & Outaneous test - \\
\hline $\boldsymbol{\theta}$ & 6 & $141 / 2$ & + & - & \\
\hline 10 & 7 & 16 & - & + & Outaneous test - \\
\hline 11 & 7 & 18 & + & + & Cutaneous test - \\
\hline 12 & 7 & $171 / 2$ & - & + & Outaneous test + \\
\hline 18 & 8 & 16 & + & + & \\
\hline 14 & 9 & 17 & - & - & \\
\hline
\end{tabular}


TABLE 13.-Tests for Protease in the Blood Serum of Infants Suffering From Chronic Malnutrition

\begin{tabular}{|c|c|c|c|c|c|c|c|}
\hline Number & $\begin{array}{c}\text { Age, } \\
\text { Months }\end{array}$ & $\begin{array}{l}\text { Weight, } \\
\text { Pounds }\end{array}$ & $\begin{array}{l}\text { Protease } \\
\text { Milk }\end{array}$ & Number & $\begin{array}{c}\text { Age, } \\
\text { Months }\end{array}$ & $\begin{array}{l}\text { Welght, } \\
\text { Pounds }\end{array}$ & $\begin{array}{l}\text { Protease } \\
\text { Milk }\end{array}$ \\
\hline $\mathbf{1}$ & 4 & $7 \%$ & + & 10 & 7 & $91 / 4$ & + \\
\hline 2 & 4 & 8 & + & 11 & 8 & $10 \%$ & + \\
\hline 8 & 5 & 9 & - & 12 & 8 & $10 \%$ & - \\
\hline 4 & 5 & 10 & + & 18 & 8 & 11 & + \\
\hline 5 & 6 & $101 / 2$ & + & 14 & 9 & 1112 & - \\
\hline 6 & 6 & 11 & - & 15 & 10 & 1236 & + \\
\hline 7 & 6 & $111 / 2$ & - & 16 & 10 & 11 & + \\
\hline 8 & 7 & $81 / 2$ & + & 17 & 12 & 1048 & - \\
\hline 9 & 7 & 10 & + & & & & \\
\hline
\end{tabular}

TABLE 14.-Subacute Intestinal Disturbances

\begin{tabular}{c|c|c|c|c|c|c|c}
\hline \hline Number & $\begin{array}{c}\text { Age, } \\
\text { Months }\end{array}$ & $\begin{array}{c}\text { Weight, } \\
\text { Pounds }\end{array}$ & $\begin{array}{c}\text { Protease } \\
\text { Milk }\end{array}$ & Number & $\begin{array}{c}\text { Age, } \\
\text { Months }\end{array}$ & $\begin{array}{c}\text { Weight, } \\
\text { Pounds }\end{array}$ & $\begin{array}{c}\text { Protease } \\
\text { Milk }\end{array}$ \\
\hline 1 & 3 & 10 & + & 10 & 7 & $141 / 2$ & + \\
2 & 3 & 9 & + & 11 & 7 & 1216 & + \\
3 & 5 & 14 & + & 12 & 7 & 14 & + \\
4 & $61 / 2$ & $181 / 2$ & - & 18 & 8 & 13 & + \\
5 & 6 & 14 & - & 14 & 8 & 1516 & - \\
6 & 6 & 18 & + & 15 & 9 & 15 & + \\
7 & 6 & $121 / 2$ & + & 16 & 10 & 13 & - \\
8 & 7 & 14 & + & 17 & 10 & 14 & + \\
9 & 7 & $181 / 2$ & + & & & & + \\
\hline
\end{tabular}

TABLE 15.-Acute Intestinal Disturbances

\begin{tabular}{|c|c|c|c|c|c|c|c|}
\hline Number & $\begin{array}{c}\text { Age, } \\
\text { Months }\end{array}$ & $\begin{array}{l}\text { Weight, } \\
\text { Pounds }\end{array}$ & $\begin{array}{l}\text { Protease } \\
\text { Milk }\end{array}$ & Number & $\begin{array}{c}\text { Age, } \\
\text { Months }\end{array}$ & $\begin{array}{l}\text { Wefght, } \\
\text { Pounds }\end{array}$ & $\begin{array}{l}\text { Proteage } \\
\text { Mill }\end{array}$ \\
\hline 1 & 4 & $11 \%$ & - & 7 & 8 & 16 & - \\
\hline 2 & 6 & $181 / 2$ & - & 8 & 8 & $181 / 2$ & + \\
\hline 8 & 6 & 14 & + & 9 & 10 & $141 / 2$ & - \\
\hline 4 & 7 & 15 & - & 10 & 11 & 1416 & - \\
\hline 5 & 7 & $151 / 4$ & - & 11 & 18 & $151 / 2$ & + \\
\hline 6 & 7 & 14 & + & & & & \\
\hline
\end{tabular}


question, an attempt to attach any definite significance to its presence would savor too strongly of speculation to be profitable.

IV. SUMMARY AND CONCLUSIONS

As shown by precipitin and anaphylactic tests applied to the urine, the intestinal tract of normal infants is usually impermeable to undigested foreign protein.

In nutritional or gastro-enteric disorders, foreign protein may be absorbed in an undigested or partially digested state and appear in the urine.

The precipitin reaction, applied to the urine for the detection of egg protein, is apparently more delicate than the anaphylactic test.

These results demonstrate the possibility that certain nutritional disorders in artificially fed infants may be due to the biologic character of the food, although they obviously give no direct evidence to support such a view.

We are greatly indebted to Professor Gies for placing the facilities of his laboratory at our disposal, and to him and his associates for much assistance.

172 West Seventy-Ninth Street-248 Collins Street. 